
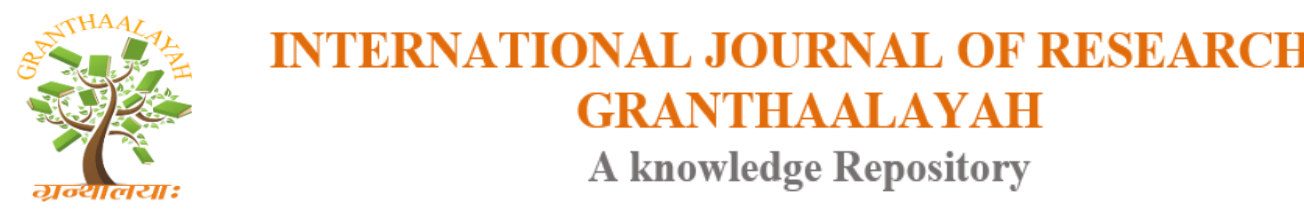

Science

\title{
CLIMATIC TOURISM MOTIVES AND THEIR ROLE IN SPATIAL ORGANIZATION AND TOURISM DEVELOPMENT OF THE NORTH- EASTERN REGION OF BOSNIA
}

\author{
dr.sc Senada Nezirović *1 \\ ${ }^{* 1}$ Department of Geography, Faculty of Science, University of Sarajevo, Sarajevo, Bosnia and \\ Herzegovina
}

\begin{abstract}
The climate of the north-eastern Bosnia belongs to the moderate continental type, where there are certain specifics caused by relief, geographic position, proximity to the Pannonian basin, mountain central massif and the distance from the Adriatic Sea. The area of northeastern Bosnia has similar climate characteristics as well as the countries of Central Europe: warm summers, cold winters, chilly autumn and rainy spirng. The climate of northeastern Bosnia is influenced by a series of factors that determine all of its elements: air temperature, humidity, air pressure and sunshine duration.

This paper analyzes the basic climatic elements of the Northeastern Bosnia region. During the field research, the emphasis was placed on climate tourism motives and their role in spatial organization and development of tourism. On the basis of a shorter analysis, we tried to distinguish tourist areas and facilities with the dominant function of tourism, in which tourism can become a dominant economic activity.
\end{abstract}

Keywords: Climatic Tourism Motives; Region of North-Eastern Bosnia.

Cite This Article: dr.sc Senada Nezirović. (2018). "CLIMATIC TOURISM MOTIVES AND THEIR ROLE IN SPATIAL ORGANIZATION AND TOURISM DEVELOPMENT OF THE NORTH-EASTERN REGION OF BOSNIA." International Journal of Research Granthaalayah, 6(7), 52-64. https://doi.org/10.29121/granthaalayah.v6.i7.2018.1283.

\section{Introduction}

\subsection{Basic Climatic Determinants of the Study Area}

The territory of the Northeast Bosnia region belongs to the northeastern part of Bosnia and Herzegovina and occupies an area of $6.628 \mathrm{~km}^{2}$ or $7.7 \%$ of the total area of Bosnia and Herzegovina. According to its geographic position, the Northeast Bosnia region is located in the central part of the former Yugoslav republics, which stands out as a favorable area for the development of transit type of tourism. 
The area is very suitable for tourist movements, has a favorable geopolitical position, is open towards the Pannonian Basin and is connected to the Adriatic coast, which is of great importance for the tourist valorization of the space. The climate of the Northeast Bosnia region belongs to the moderate continental type, with certain specifics caused by relief, geographical position, proximity to the Pannonian basin, mountain central massif and the distance from the Adriatic Sea. The climate of the Northeast Bosnia region is conditioned by a series of factors that determine all of its elements: air temperature, humidity, air pressure, and sunshine duration.

The annual thermal regime in this area is completely moderate to the continental climate, where the hottest month is July, according to the layout of the isotherms, with higher temperatures in the northern region compared to the southern mountainous.

Air temperature is an important climatic element, it has a special significance in tourism valorization of climatic conditions, of the utmost importance for bathing and sports and recreational tourism. The temperature determines the length of hot days of the year, which is 180 days, of which 70 are with temperatures higher than $25^{\circ} \mathrm{C}$, while 80 days with temperatures below $0^{\circ} \mathrm{C}$. The frost appears from October to April. In the valley of the Drina river 80 days is frozen solid, and in the mountains to 150 days (Atlas klime SFRJ, 1991.).

Table 1: Temperatures in the Drina river valley and on the mountains above 1000 meters above sea level

\begin{tabular}{|l|l|l|}
\hline Temperature & $\begin{array}{l}\text { The flow of the river Drina 224. } \\
\text { mamsl }\end{array}$ & $\begin{array}{l}\text { Moutains above 1000. } \\
\text { mamsl }\end{array}$ \\
\hline $\begin{array}{l}\text { The mean daily } \\
\text { temperatue }\end{array}$ & $4,0^{\circ} \mathrm{C}$ (January) to $28,7^{\circ} \mathrm{C}$ & $\begin{array}{l}-0,4^{\circ} \mathrm{C} \text { (January) to } 21^{\circ} \mathrm{C} \\
\text { (July) }\end{array}$ \\
\hline Annual amplitude & $24,7^{\circ} \mathrm{C}$ & $21,4^{\circ} \mathrm{C}$ \\
\hline $\begin{array}{l}\text { The mean daily } \\
\text { temperatue }\end{array}$ & $-5,7^{\circ} \mathrm{C}$ ( January) to $13,1^{\circ} \mathrm{C}$ (July) & $\begin{array}{l}-8,5^{\circ} \mathrm{C} \text { (January) to } 8,4^{\circ} \mathrm{C} \\
(\mathrm{July})\end{array}$ \\
\hline Annual amplitude & $18,8^{\circ} \mathrm{C}$ & $16,9^{\circ} \mathrm{C}$ \\
\hline
\end{tabular}

Source: Atlas klime SFRJ, 1991: Hidrometeorološka služba SFRJ,Savezni hidrometeorološki zavod, meteorološki godišnjaci 1971-1991. Special hunting ground of Sušica: Hunting grounds and game records until 2015, Srebrenica.

Bear in mind that for the development of tourism it is necessary to have a significant number of sunny days. It is of great importance to use the indicator of the length of the sun's insolation (Milosavljević, 1977). Annual insolation is moderate, up to 1800 hours in Bijeljina and Brcko District. At the Pannonian lakes in Tuzla that is 1750 , while on the lake Perucac in Srebrenica 1700 hours. The most sunny days are in August and the least in December. Increased insolation due to diluted air at lower summer temperatures is a significant recreational value of mountain climate. Thanks to the increased insolation during the winter period in the mountain area at temperatures below $0^{\circ} \mathrm{C}$ one does not feel too cold. 
Table 2: Insolation in hours at the Pannonian lakes and the Lake of Perucac

\begin{tabular}{|l|c|l|l|l|l|l|l|l|l|l|l|l|l|l|l|}
\hline Months & I & II & III & IV & V & VI & VII & VIII & IX & X & XI & XII & Daily & monthly & annualy \\
\hline $\begin{array}{l}\text { Panonska } \\
\text { jezera } \\
\text { /Tuzla) }\end{array}$ & 72 & 85 & 114 & 146 & 180 & 212 & 237 & 240 & 198 & 145 & 66 & 55 & & 48 & \\
\cline { 2 - 15 } & 2,3 & 3 & 3,6 & 4,8 & 5,8, & 7,1 & 7,6 & 7,7 & 6,6 & 4,6 & 2,2 & 1,7 & 2,2 & & 1750 \\
$\begin{array}{l}\text { Jezero } \\
\begin{array}{l}\text { Peručac } \\
\text { (Srebnica) }\end{array}\end{array}$ & 68 & 81 & 109 & 144 & 177 & 203 & 232 & 235 & 184 & 143 & 73 & 51 & & 46 & \\
\cline { 2 - 14 }
\end{tabular}

Source: Atlas klime SFRJ,1991: Hidrometeorološka služba SFRJ, Savezni hidrometeorološki zavod, meteorološki godišnjaci 1971 - 1991. Beograd, Službene novine TK 9/06 2008: Prostorni plan za područja TK 2005-2015 godine, Tuzla, Statistički godišnjak RS, 2014, Banja Luka.

The basic characteristic of the thermal regime in the Northeast Bosnia region is the decrease of the temperature from north to south in parallel with the increase of the altitude.

Low winter temperatures are caused by winter cover, which remains longer on mountains Konjuh and Javor, which provides the ability to walk through the snowy landscape or to enjoy a stroll around the area. High summer temperatures make the weather ideal for mountain, spa and rivers. Warm days range from the middle of June to the middle of September, allowing complementary types of tourism: spa, walking and sports-recreational tourism.

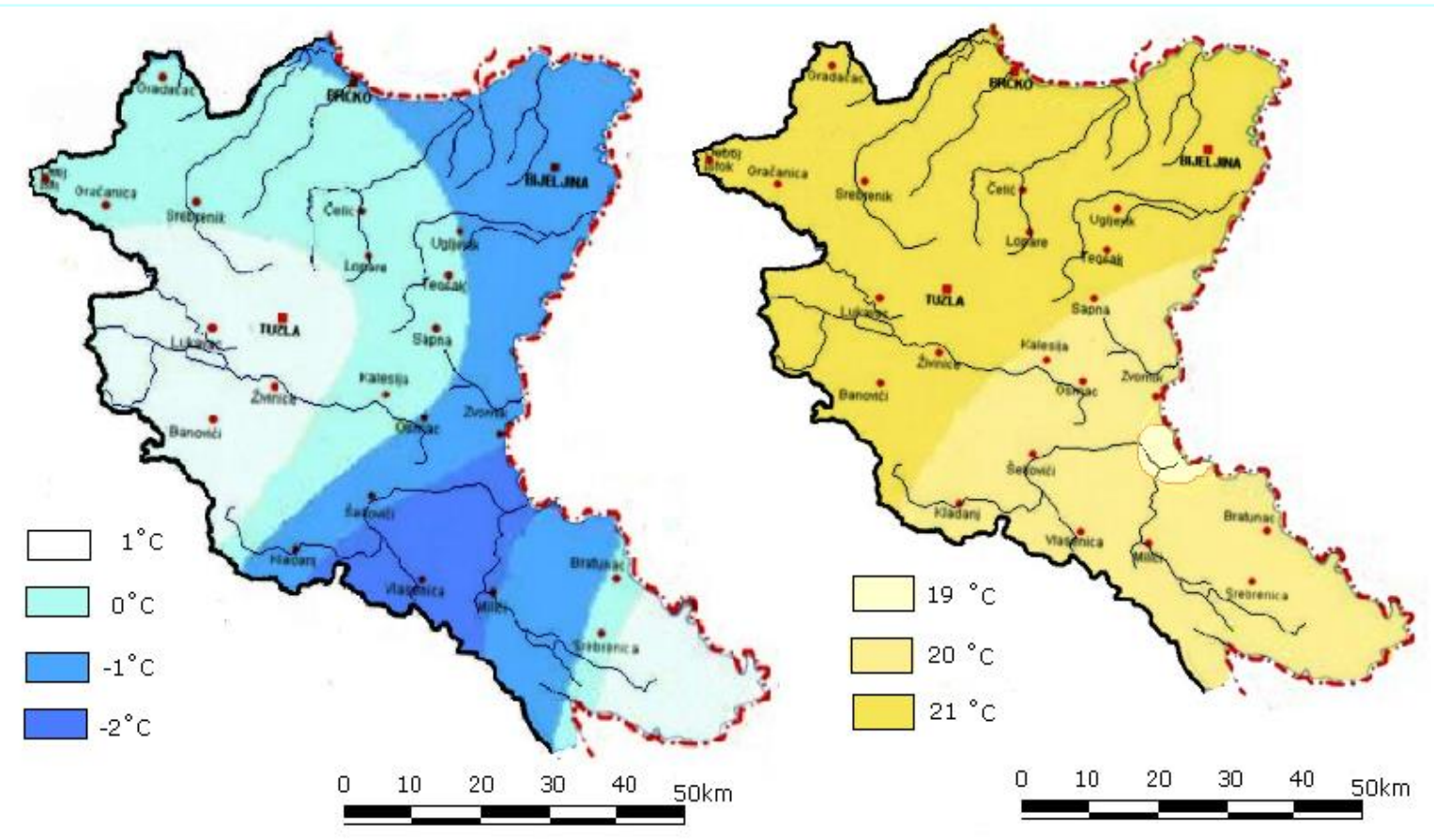

(Source: S. Nezirović)

Figure 1: Geographical distribution of annual isotherms

Cloudiness, as an important climatic element is proportional to the amount of rainfall, and inversely proportional to insolation. Greater cloudiness reduces sunlight and lowers daily air temperatures, which affects the retention and stay of visitors in nature. The average cloudiness of 
the Northeast Bosnia region is $5 / 10$ cloudy skies (Atlas climate SFRJ, 1991). The biggest cloudiness is during the winter months: in November, December and January; lowest in: July, August and September - below 50\% (the geological composition of the area and forests is influenced by cloudiness).

Table 3: Average annual cloudiness in \%, in the Spreča valley in Podrinje

\begin{tabular}{|l|r|l|l|l|l|l|l|l|l|l|l|l|l|}
\hline & I & II & III & IV & V & VI & VII & VIII & IX & X & XI & XII & Yr. \\
\hline Spreča Valley (Lukavac ) & 71 & 70 & 67 & 62 & 60 & 54 & 43 & 38 & 42 & 54 & 72 & 75 & 59 \\
\hline Podrinje (Srebrenica) & 61 & 62 & 60 & 55 & 59 & 36 & 39 & 35 & 39 & 46 & 73 & 71 & 54 \\
\hline
\end{tabular}

Source: Atlas klime SFRJ, 1991: Hydrometeorological department of SFRJ, The Federal Hydrometeorological Institute, Meteorological yearbook 1971 - 1991. Belgrade, Gazette TK 9/06 2008: Spatial Plan of TK until 2015, Tuzla, Statistical Yearbook RS, 2014, Banja Luka.

Precipitation amounts to $1030 \mathrm{~mm} / \mathrm{m}^{2}$. The majority of the territory of the Northeast Bosnia region is located within an isohyet of 800 to $1000 \mathrm{~mm}$. Mountain areas have slightly larger precipitation, from 1000 to $1250 \mathrm{~mm}$.

Annually is excreted around $850 \mathrm{~mm}$ in Semberija and the lower Podrinje area (valley), and 1250 $\mathrm{mm}$ on the mountain Javor. Annual average rainfall ranges from 75 to $86 \mathrm{~mm}$. The maximum rainfall of 88 to $127.4 \mathrm{~mm}$ is during May and June, with a minimum of $60 \mathrm{~mm}$ in February. The most snowy precipitation is coming out on the mountains. The height of the snow cover is $90 \mathrm{~cm}$, while in river valleys up to $35 \mathrm{~cm}$ (Statistical Yearbook RS, 2013).

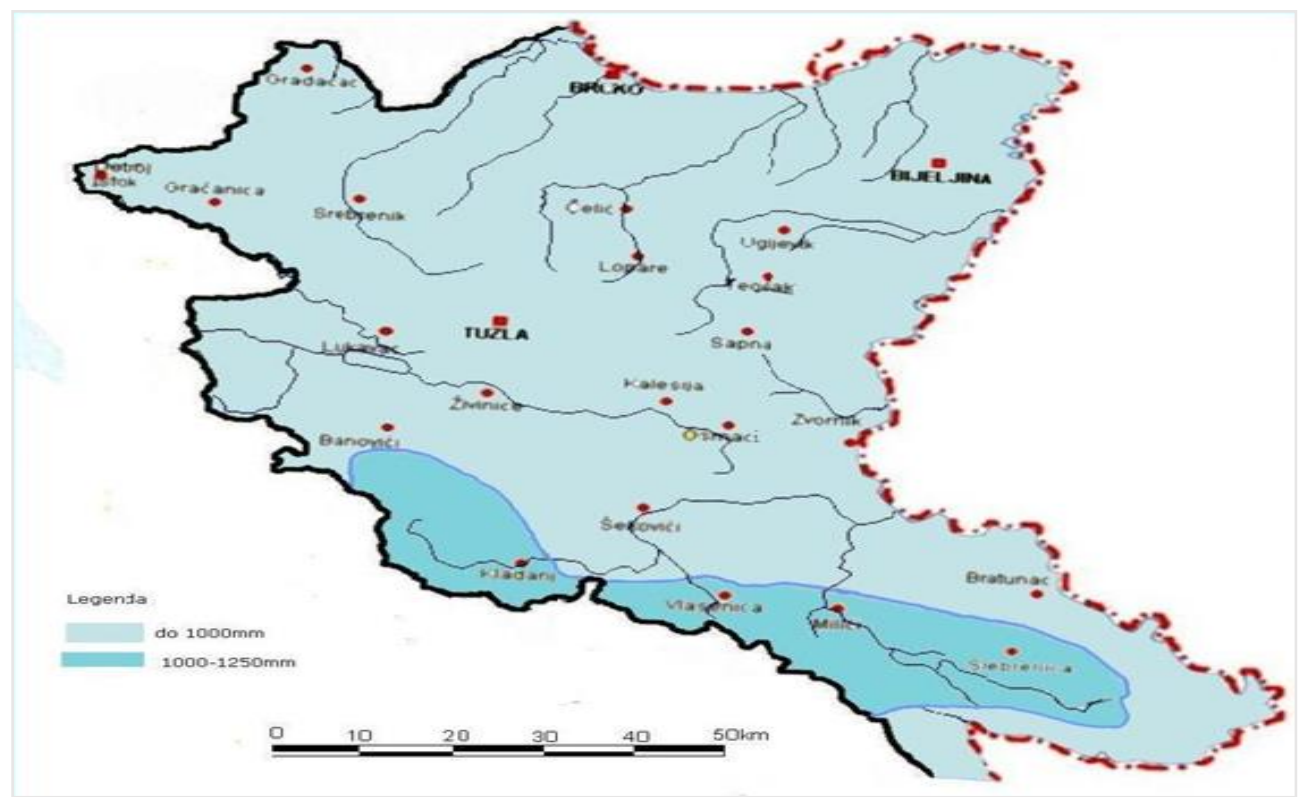

(Source: S. Nezirović)

Figure 2: Rainfall in the region Northeast Bosnia

Relative humidity is important for tourist movements. The most favorable humidity is $60-70 \%$, at a temperature of $20{ }^{\circ} \mathrm{C}$ and the wind speed of $1 \mathrm{~m} / \mathrm{s}$. The average annual relative air humidity in the Spreča valley is $76 \%$, at the foot of the mountains: Majevica, Ozren and Trebavac- up to $80 \%$ (Spatial Plan for TK areas by 2015).The highest values are during the winter months and the least 
during the month of April. In the wooded Vlasenica and Srebrenica area, relative humidity is $81 \%$ (Nezirović, 2011).

Table 4: Relative humidity for the period 1971-2012.

\begin{tabular}{|c|r|l|l|l|l|l|l|l|l|l|l|l|l|}
\hline & I & II & III & IV & V & VI & VII & VIII & IX & X & XI & XII & Yr. \\
\hline Tuzla basin (Tuzla) & 84 & 87 & 73 & 68 & 73 & 74 & 73 & 73 & 76 & 79 & 82 & 85 & 76 \\
\hline Podrinje (Srebrenica) & 88 & 85 & 79 & 73 & 78 & 77 & 77 & 76 & 81 & 85 & 85 & 89 & 81 \\
\hline
\end{tabular}

Source: Atlas klime SFRJ 1991: Hydrometeorological department of SFRJ, The Federal Hydrometeorological Institute, Meteorological yearbook 1971 - 1991. Belgrade, Gazette TK 9/06 2008: Spatial Plan of TK area 2005-2015, Tuzla, Statistical Yearbook RS, 2013, Banja Luka.

The mountainous region of Northeast Bosnia has a favorable relative humidity. Specifically, these climate benefits positively influence: anemia, high blood pressure, heart, lung and other disorders, hence it is favorable for recreational and health-healing therapeutic components.

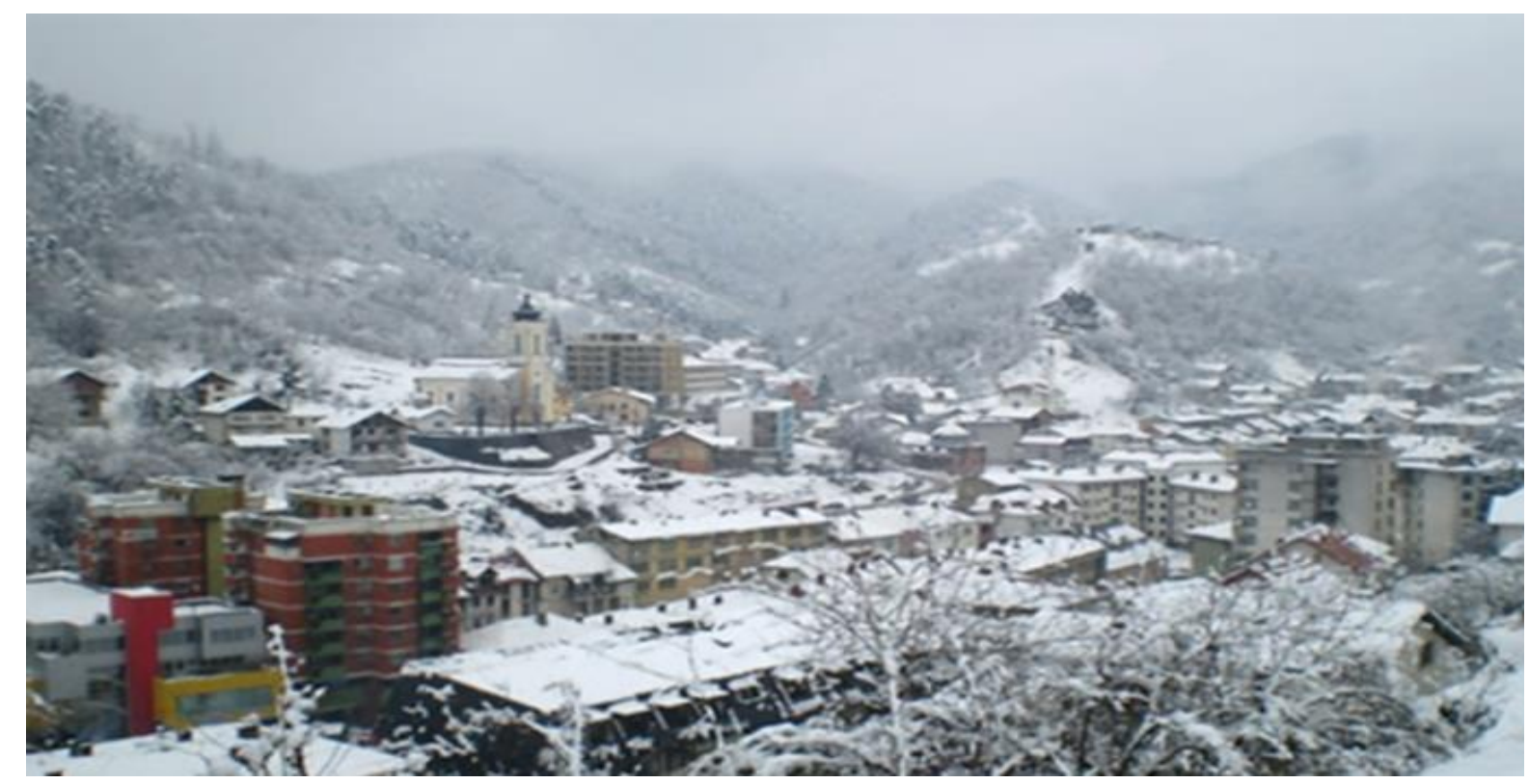

(Shot by: S. Nezirović)

Figure 3: Winter scenery in Srebrenica

The change of microclimate is influenced by the large amount of pollutant emissions above the industrial centers (Tuzla and Lukavac). Due to higher concentrations of harmful particles in the air above the town of Tuzla, the relative air values reach $79 \%$ (the highest values are in December 85\%, the lowest in March and April 72\%), so the annual amplitude is 13\%. Increased values of air humidity affect the appearance of various allergens, such as: dust, fungi and various pollen (Stojaković, 1991). During the fall and winter in Tuzla basin there is a significant presence of fog (Spatial Plan for areas of Tuzla Canton by 2015.)

Table 5: Number of days with fog in Tuzla basin

\begin{tabular}{|l|l|l|l|l|l|l|l|l|l|l|l|l|l|}
\hline Months & I & II & III & IV & V & VI & VII & VIII & IX & X & XI & XII & Yr. \\
\hline Measuring station in Tuzla & 8 & 4 & 3 & 2 & 4 & 3 & 2 & 2 & 4 & 8 & 7 & 9 & 56 \\
\hline
\end{tabular}

Source: Spatial Plan for area of TK 2005-2015, Tuzla. 


\section{Objectives}

In this paper we present the results of this study. Analysis of climatic areas within $\mathrm{C}$ climate:

- The $\mathrm{Cfb}$ climate zone, which is a moderately warm and humid climate with a warm summer,

- The Cfe climatic zone that represents a moderately warm and humid climate with a fresh summer,

- The Dfc area which represents a moderately humid climate with fresh summer,

- Presentation of climatic tourist motives and their role in the spatial organization and development of tourism.

\section{Materials and Methods}

The research methodology required the use of data that was to be taken from a variety of sources, with the exception of professional literature, planning documents, maps, draft maps and statistical indicators. The collected work material and data are, according to their structure, processed by contemporary geographic methods including GIS technology for presentation of geographic reality of the Northeast Bosnia region.

\section{Results and Discussions}

\subsection{Valorization of climate motives in the region of Northeast Bosnia}

By the Kepen's Climate Classification, Northeast Bosnia belongs to the C Climate Zone. Within the $\mathrm{C}$ climate, singled out are the $\mathrm{Cfb}$ climate, which is a moderately warm and humid climate with warm summer, the Cfe climate with a moderately warm and humid climate with fresh summer and the Dfc climate with a moderately humid climate with a fresh summer (Separat SR Bosna i Hercegovina, Jugoslovenski lek. zavod, Zagreb, 1983, pg.29-30).In river valleys and hilly areas penetrate the influences of moderate continental climate that differs from moderately continental to the north and mountainous in the southeastern area.

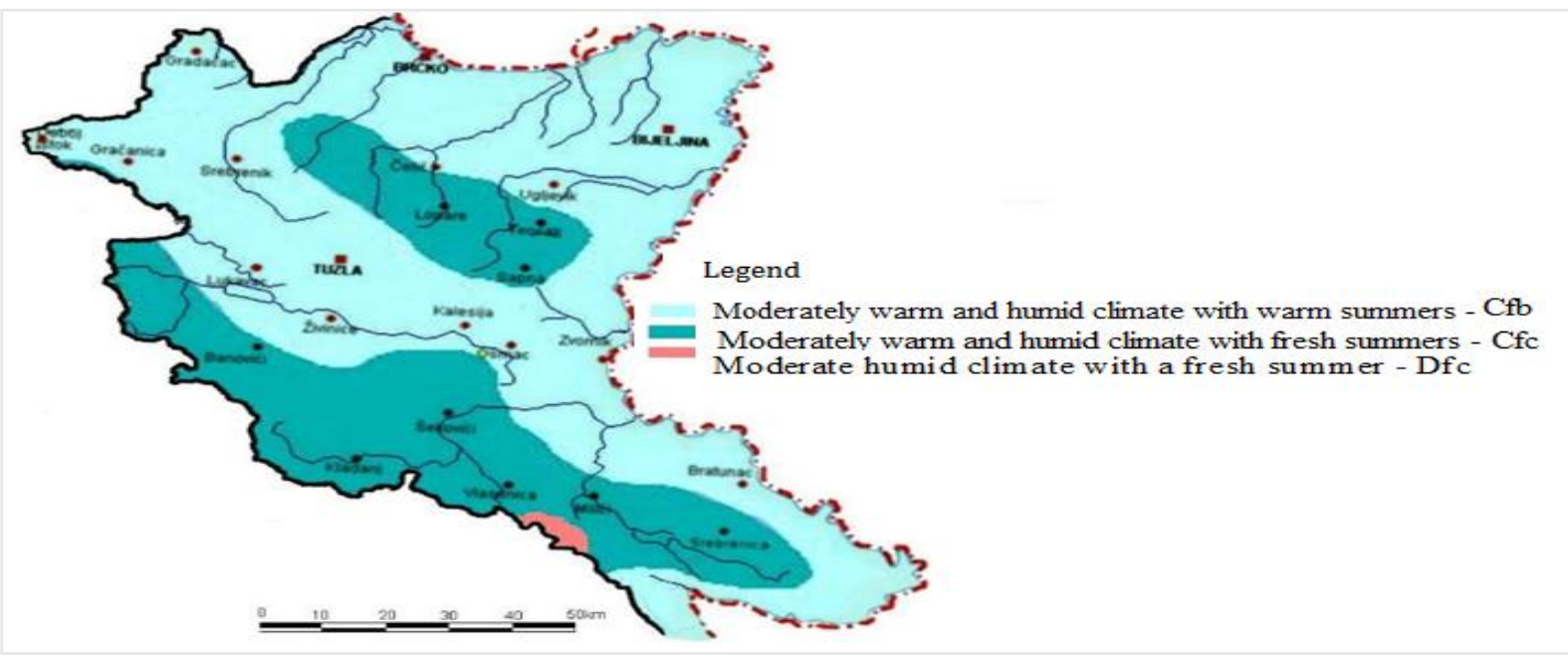

Figure 4: Geographical distribution of climatic types of the Northeast Bosnia region (S. Nezirovic) 


\subsubsection{Moderately Warm and Humid Climate with Warm Summers - Cfb}

Moderately warm and humid climate with warm summers - Cfb represented in the valleys of the rivers Sava and Drina Spreča, up to 300 mamsl It is characterized by an average annual temperature $11,2^{\circ} \mathrm{C}$, and precipitation $700-850 \mathrm{~mm} / \mathrm{m}^{2}$. The hottest month is July, with an average temperature of $21^{\circ} \mathrm{C}$.

In the valley of the Sava River, the summers are warm, the winters mostly moderately cold, the maximum precipitation is during the summer and the minimum is at the end of the winter. The average rainfall in Bijeljina is $850 \mathrm{~mm}$. On average, the snow is kept 40 days a year. Relative humidity is $70-80 \%$. The coolest month is January with an average temperature of $-1.4^{\circ}$ to $3.7^{\circ}$ $\mathrm{C}$ and the hottest is July with an average temperature of $21^{\circ} \mathrm{C}$. The average January temperature is $-0.8^{\circ} \mathrm{C}$. Annual temperature fluctuation is between 20 and $23^{\circ} \mathrm{C}$, indicating that these areas of the Brcko District and Bijeljina have more pronounced features of thecontinental climate (Atlas Climate SFRJ, 1991).

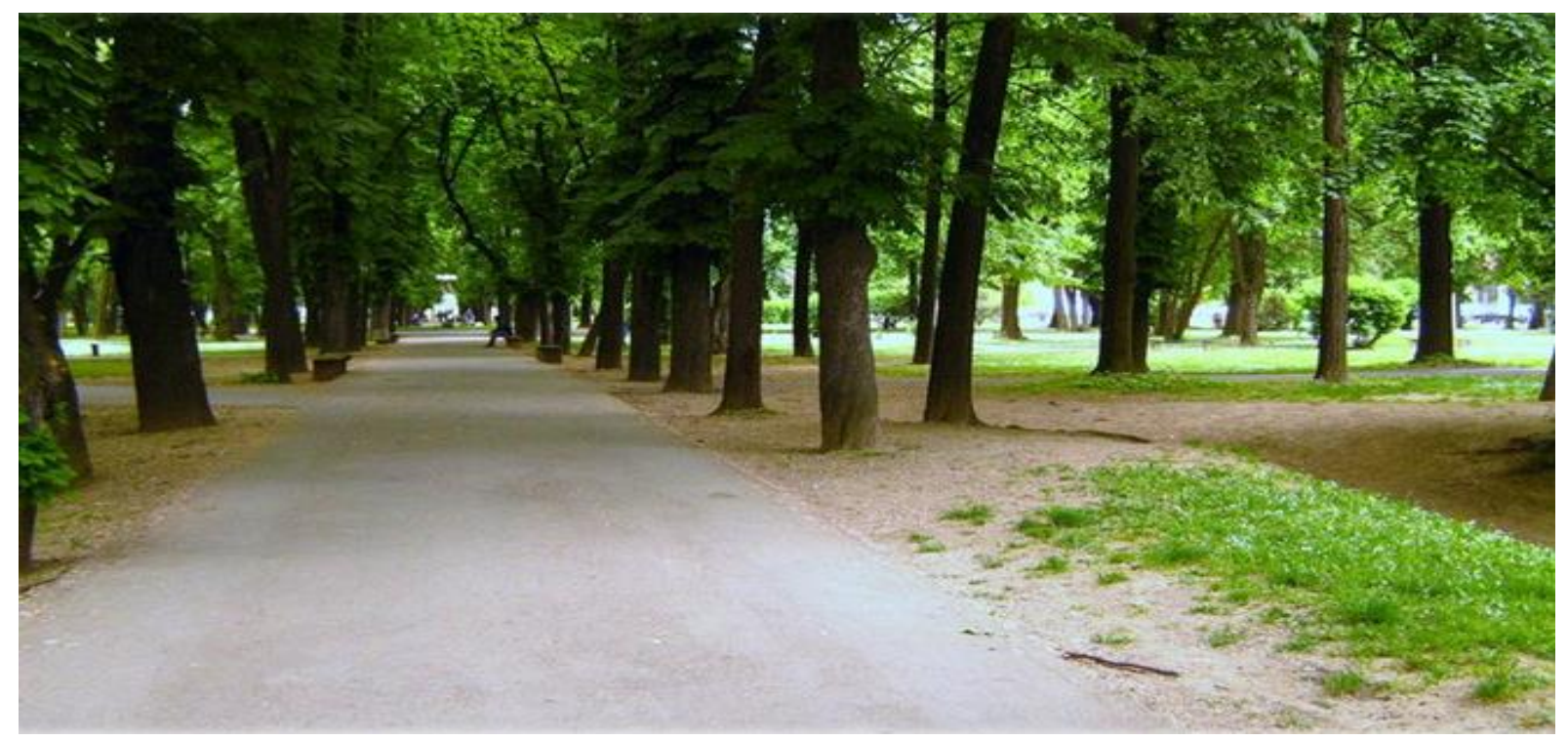

Figure 5: City park in Bijeljina, summer ambience

(Source: https://www .obidjibosnu)

In the valley of the river Spreca summers are significantly warm, but not unbearable heat, the nights are pleasant and slightly cooler. The transitional season is clear, autumn is warmer than spring. The average July air temperature is $19.6^{\circ} \mathrm{C}$, January $-1^{\circ} \mathrm{C}$. The average annual temperature is $11.2^{\circ} \mathrm{C}$ (Study Program and Spatial Plan of Tourism Development in Northeast Bosnia, Department of Economics, Tuzla 1977).

Precipitation is stronger in spring and autumn, maximum precipitation is in May (in Gračanica $121 \mathrm{~mm}, 122 \mathrm{~mm}$ Tuzla, Kalesija $109 \mathrm{~mm}$ ), the minimum in February (Gračanica $51 \mathrm{~mm}, 68 \mathrm{~mm}$ Tuzla, Kalesija $97 \mathrm{~mm}$ ). Precipitation days is 90-150 (Spatial Plan for the area of TK 2005-2015.). Snow falls here are in January, February and March. There are 50 snowy days in the Lower Spreca, and 61 in the Upper Spreča. 


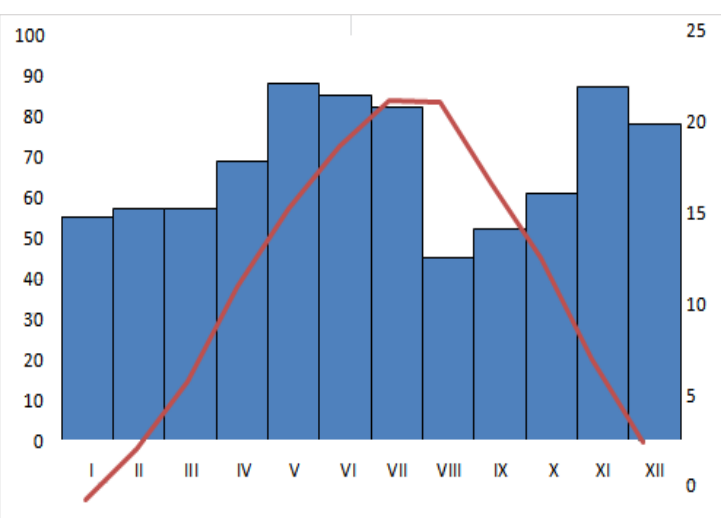

Bijeljina

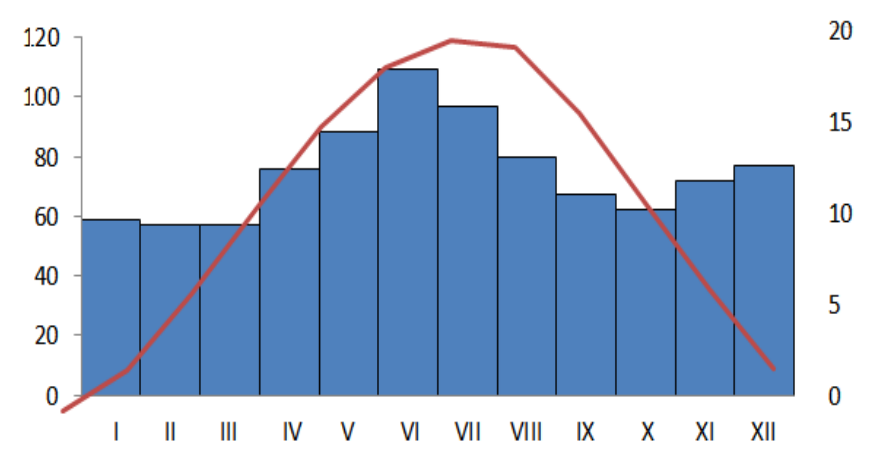

Tuzla

Figure 6: The average annual flow of the pluviometric regime in Bijeljina and Tuzla (S. Nezirović)

During the summer months in the Sava and Drina valleys, in the area of: the Brcko District, Bijeljina and the very south part of Srebrenica, due to high temperatures and lack of moisture in the country, a summer drought appears, and where the hydrostatic dryness coefficient is at the drying limit. Milosavljevic states that the northern plain areas of the Northeast Bosnia region have a moderate drop and increase in drought, with the exception of Semberia and the Drina valley, the southern predominantly lowlands have a smaller decline and increase. This is understandable because the summers are dry and winters are rainy (Milosavljevic, 1977, 79-89.).

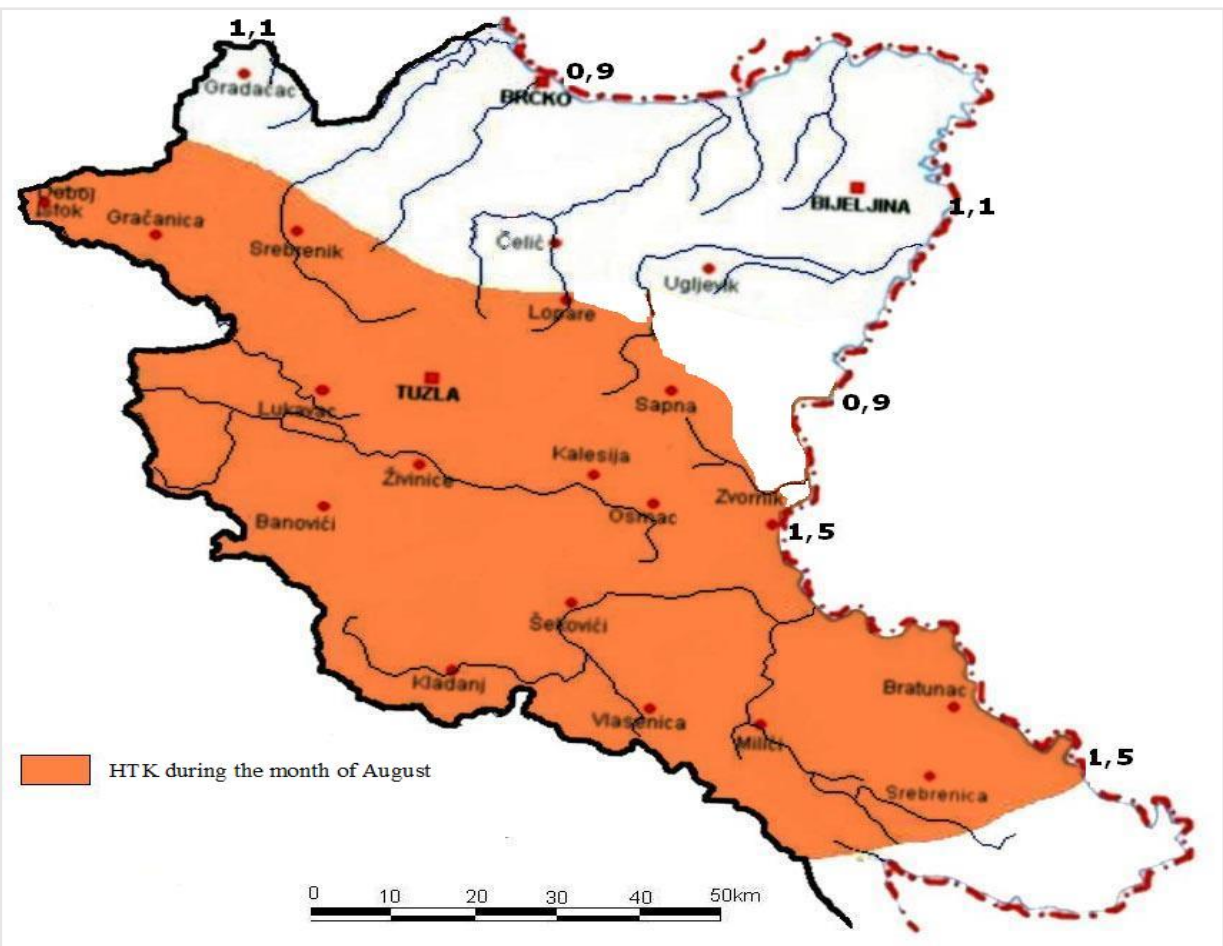

Figure 7: Hydrothermal Coefficient (HTC) of drought

(The map made by: S. Nezirović) 


\subsubsection{Moderate Warm and Humid Climate with Fresh Summer - Cfc}

Moderately warm and humid climate with fresh summers-cfc, prevails in the middle, mountain region up to 800 meters above sea level. It is distinguished by more cool summers; the average rainfall is $900 \mathrm{~mm} / \mathrm{m}^{2}$, and the mean annual temperature is $10{ }^{\circ} \mathrm{C}$ on the slopes of Ozren, where the average height is between 30 and $40 \mathrm{~cm}$. In climatic terms, the lower parts of the Majevica region have a typical moderate-continental climate, and the higher subsistence have pre mountain and mountain climate. There are also larger microclimate differences, which are conditioned by relief. The Majevica Mountain represents a climatic border between the Sava and Preca region, whereby the so-called Majestic type of climate, which protects the Tuzla-prevented bail from the direct impact of air masses from the Pannonian Plain. Mountain Majevica is a region of colder and cleaner air, it is encouraging for recreation, and it has cooler summers and relatively mild winters. Rainfall is stronger in the spring and autumn, from the slopes of the Majevica local winds to the rivers: Sava, Spreca, Drina and Bosna. As the Majevica Mountain protects the Spreca Valley from the direct impact of air masses from the Pannonian Plain, and the slopes of the Ozren and Konjuh mountains prevent the air from the south from forming the boundary of a substantial and moderate continental climate. The mountains of Ozren and Konjuh have high air pressure, which conditions the air currents towards the valleys: Bosna, Sprece and Drina. Higher influence of the sub planetary climate has: Kladanj, Vlasenica and Srebrenica, whose altitudes reach up to 1,000 $\mathrm{m}$ in relation to: Janja, Kozluk and Zvornik (142 m / nv). These sites represent very important independent and complementary tourist resources, which with natural and social resources are valuable and important areas for tourist development of the Region.

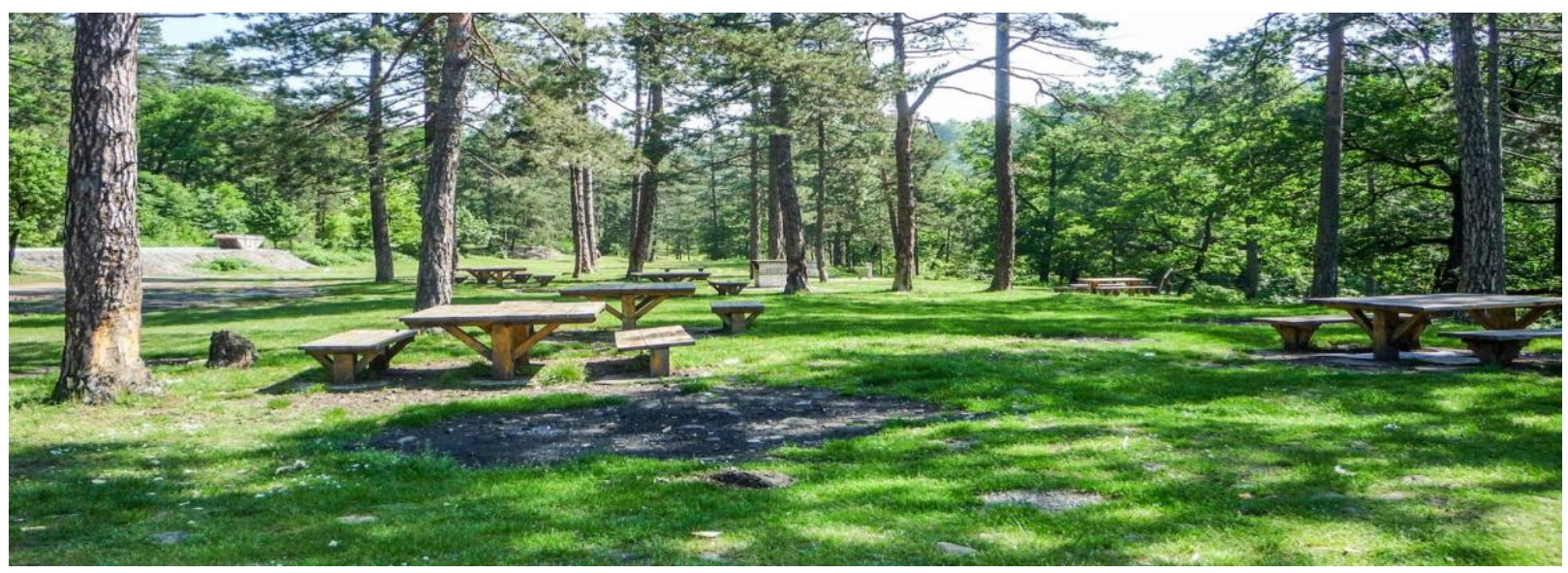

Figure 8: Summer climate ambient Mackovac-Konjuh

(Source: https://:https://turizambanovici.ba/izletiste-mackovac/

The area of Drinjača and Bratunac has less moderate continental differences compared to the forest area of Birač, which is defined by clean air.

Bratunac basin and mountain range significantly affect the microclimate of the Srebrenica region, which affects the low wind speed. Winters are slightly colder than $-1.8^{\circ} \mathrm{C}$, up to $-3.5^{\circ} \mathrm{C}$. The summers are moderately warm, the average July temperatures are $20^{\circ} \mathrm{C}$. Autumn is warmer than spring. The average annual temperature is slightly lower than $10^{\circ} \mathrm{C}$. The temperature determines the length of hot days of the year, which is 180 days, of which 70 days are at temperatures above $25^{\circ} \mathrm{C}$ and 80 days at temperatures below $0{ }^{\circ} \mathrm{C}$. 


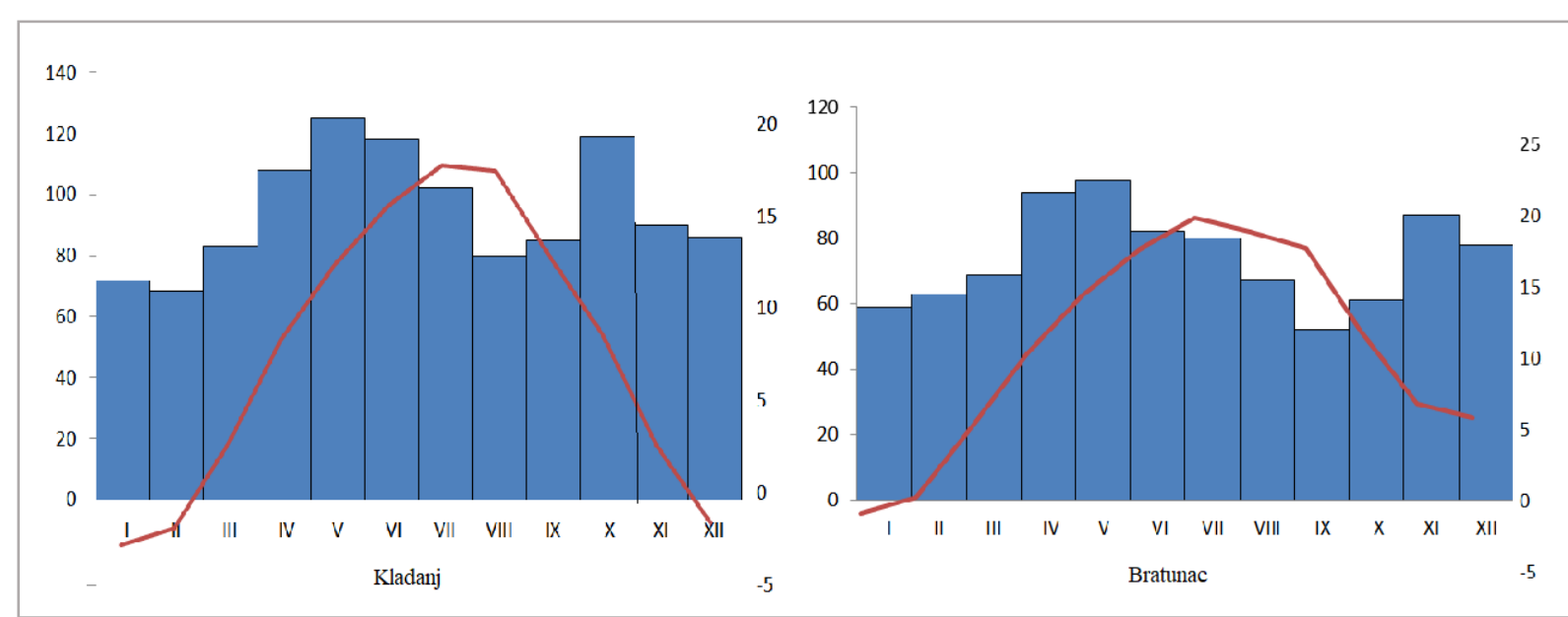

Figure 9: Average annual flow of the pulmonary system in Kladanj and Bratunac (S. Nezirovic)

The southeastern mountainous area and parts of Birača, above 1,000 m sea level of the Srebrenica and Vlasenica regions, are much damper than the northern Sava Valley. Forested area: Vlasenica, Šeković and Srebrenica are characterized by clean air, rich in high oxygen content and a fresher climate, suitable for recreation and walking, which enables the development of health oriented recreational tourism. (Nezirović, 2009).

\subsubsection{Moderate Humid Climate with A Fresh Summer - Dfc}

Moderate humid climate with fresher summers - dfc prevails in the southern, mountainous region, above $1.000 \mathrm{~m}$ high, with temperature of $9.5^{\circ} \mathrm{C}$ and rainfall of $1.100 \mathrm{~mm} / \mathrm{m}^{2}$ (Separat: SR Bosnia and Herzegovina, 1983). The southern mountainous area of Javor is characterized by fresh summers (the warmest month has an average air temperature lower than $18^{\circ} \mathrm{C}$ ). Negative air temperatures, below $-0^{\circ} \mathrm{C}$, last from October up until April, in January $-3^{\circ} \mathrm{C}$. The greatest quantities of rain are May, where $127 \mathrm{~mm}$ of rain falls (Atlas climate SFRY, 1991). Snowfall is extensive and long lasting. At Visokim Igrištima and Zlovrhu there is a total of 150 days of frost (Urban Planning Institute of RS, 2008: Spatial Plan of Republika Srpska until 2015, Banja Luka).

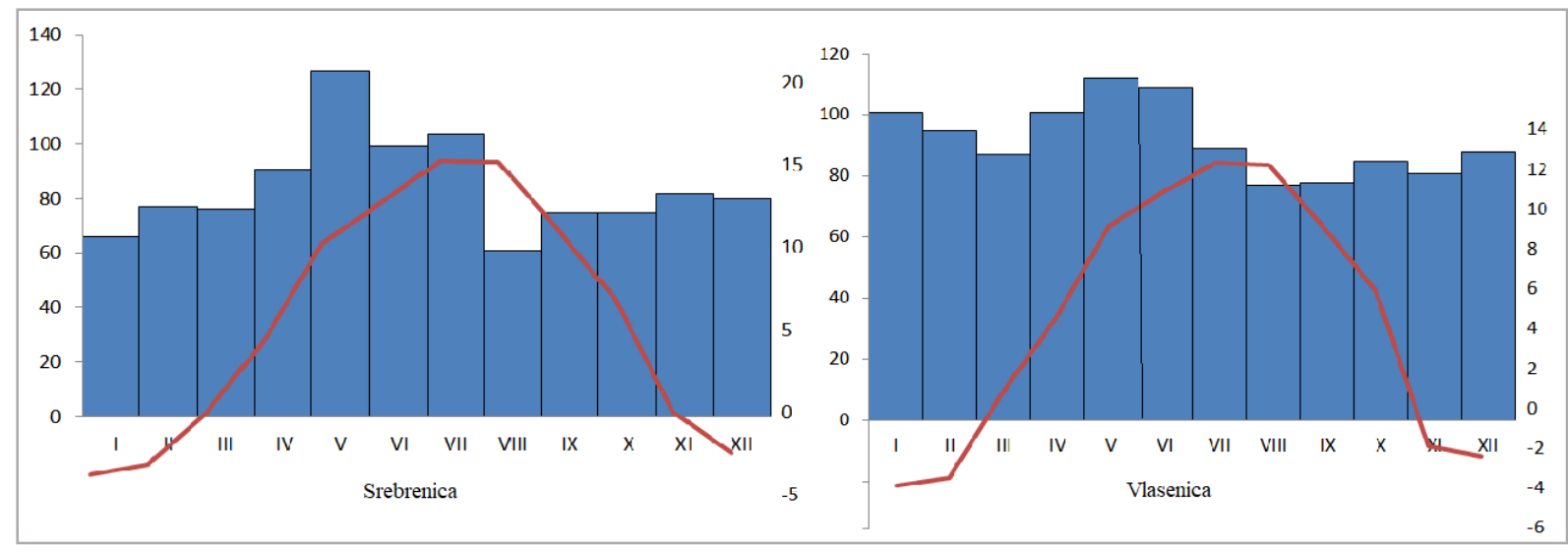

Figure 10: Average annual flux of the pulsimetic regime in Srebrenica and Vlasenica (S. Nezirovic) 
The southern mountain area of the region of Northeast Bosnia is characterized by mild climatic conditions, which together with clean air and preserved nature, represent a combination of health and psycho-physical refreshment.

Based on the above climatic indicators, the following can be noted: the region of Northeast Bosnia is the contact area between the Pannonian Plain and the Dinarides, its final plain part is at the transition of steppe-continental into a moderate continental climate. More pronounced features of the mountain climate are in the far south, due to the significant altitude of $1,537 \mathrm{~m}$, on the Javor Mountain.

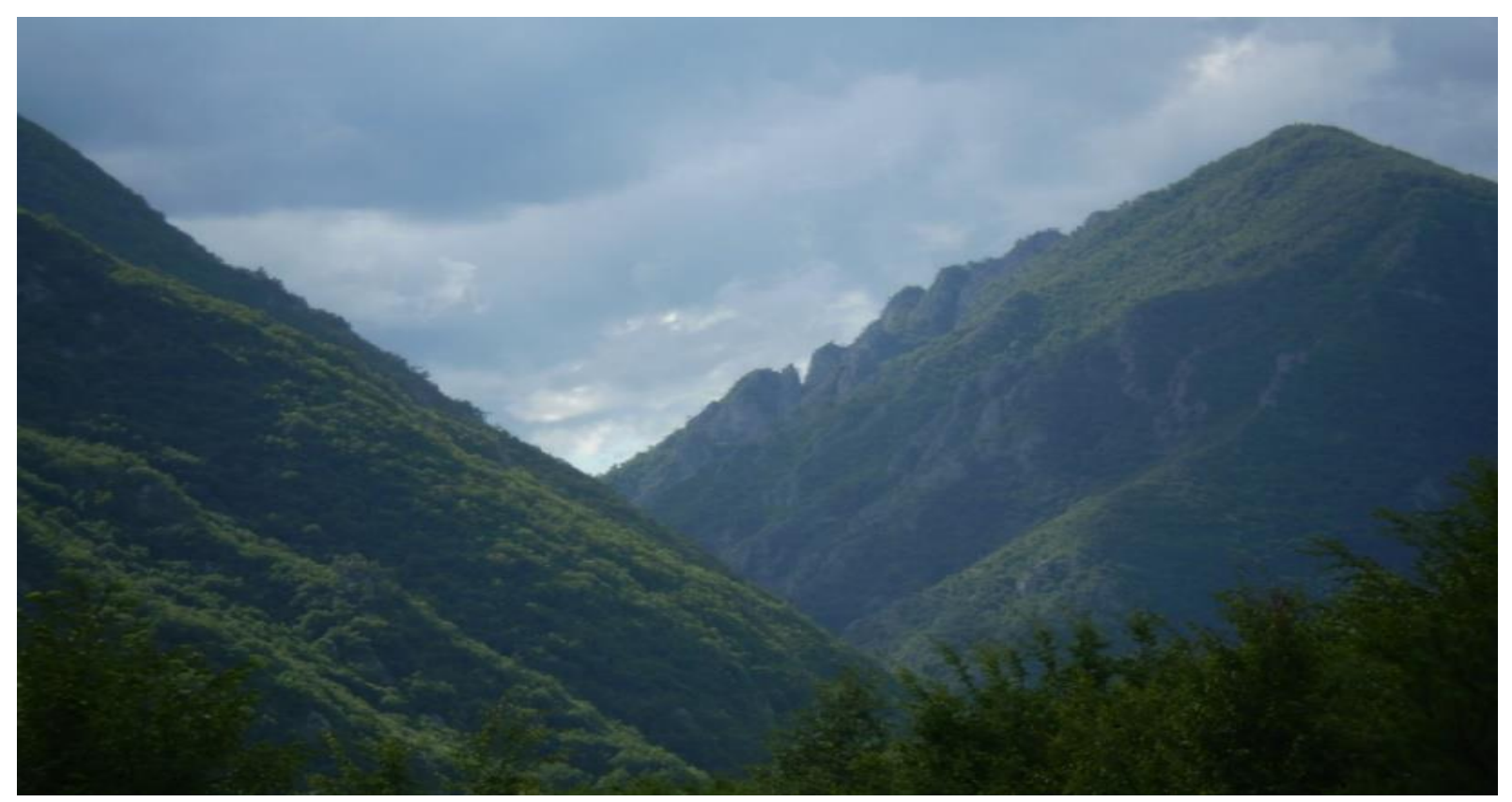

Figure 11: Top of the Susica during summertime

(Shot by: S. Nezirovic)

\section{Conclusions}

Based on the above climatic indicators, the following state can be noted: as the northeastern Bosnia is the connection area between the Pannonian Plain and Dinarides, its final plain part is located at the transition of steppe-continental into a moderate continental climate. In the small area of the extreme south, due to the significant altitude of $1537 \mathrm{~m}$, the Javor Mountain has snowy winters; fresh summers, rainy springs and slightly warmer autumns with rainfall. Climate tourist resources are one of the main natural elements, which are helping the development of tourism in the region of Northeast Bosnia. The climate is a complementary touristic motive, but it can also act in a recreational way. The length of time visitors' stay in nature, recreation, walking, feeling of comfort and relaxation are significantly influenced by climatic elements: insolation (sun energy), humidity, air temperature, winds and precipitation. From the touristic and geographical aspect, the mountainous climate in the southwestern and western regions and the sub mountain climate is moderately continental type in the eastern and central parts, which differs from the moderate continental in the north and the mountainous climate in the southeastern mountainous region of the North-East Bosnia. 
Based on the analysis of the climate tourism trends of the region of Northeast Bosnia and the form of tourism of certain zones, tourist facilities should be activated. For each of the above forms, study of tourist should be developed, which will provide guidelines for future development. The spatial arrangement of climatic tourist motives and their effect on the development of tourism is not the same in the whole area. These differences can be accompanied by uneven economic development and different population density of certain parts. This means that the use of these touristic motives in the development of tourism, in the region of the North-East Bosnia, is conditioned by changes in the economy and society, such as: greater investment in the development of tourist infrastructure, number of visitors, and the volume of daily and overall consumption. Therefore, the activation of all motives and the creation of a stronger base of offers for tourists depend on a number of factors. In connection with this, the development of tourism and its impact on the overall economic development of the region of Northeast Bosnia is a subject to further consideration.

\section{Acknowledgement}

We wish to express our gratitude to the Ministry of Trade, Tourism and Transport of Tuzla Canton, for providing us with the insight into its documentation and for contributing to the writing of this research paper. We would also like to thank the Ministry of Social Affairs of the Bijeljina municipality, the Brčko District Government, the Department for Economic Activities of the Srebrenica municipality, the manager of the hunting grounds Posebno Sušica in Srebrenica, the manager of the special hunting area Konjuh in Kladanj, Tuzla and Kladanj commercial enterprises of Šume TK, Mayor of the Kladanj municipality, Panonika commercial enterprise in Tuzla for allowing us to access and use their documentation that contributed greatly to the writing of this paper.

\section{References}

[1] Archive of Srebrenica Municipality, 2017.

[2] Archive of the Municipality of Tuzla, Service for Social Activities of the Municipality of Tuzla, 2017.

[3] Archive of the Municipality of Vlasenica Department for Urbanism and Spatial Planning, Vlasenica, 2017.

[4] Archive PD Konjuh, Tuzla, 2017.

[5] Archives PD Majevica, Srebrenik, 2017.

[6] Atlas of the SFRY Climate, Hydrometeorological Service of the SFRY, Federal Hydrometeorological Institute, Meteorological Yearbooks 1971-1991. Belgrade, 1991.

[7] Bosnia and Herzegovina: Sights and Beauties, Sarajevo,1996.

[8] Ćatović, A.,Tourism in the Economic Structure of the Region of Northeast Bosnia. Novi Sad.

[9] Dreskovic, N.; Mirić, R. Regional Geography of Bosnia and Herzegovina. PMF, Sarajevo, 2017.

[10] Encyclopaedic - tourist guide: Goods on the roads of Yugoslavia, Belgrade, 1983.

[11] Study on the program and spatial plan for the development of tourism in the area of northeastern Bosnia, Institute for economics, Tuzla, 1977.

[12] Proceedings of the Expert Works, Company for Tourism, Recreation and Treatment "Guber"Srebrenica, 1976.

[13] Milosavljević R., Geographical Overview of the XXI, Geographical Society of BiH, drought and its distribution in BiH, Sarajevo, 1977, p. 79-89.

[14] Ministry of Trade, Tourism and Traffic TK, Government of Tuzla Canton, Tuzla, 2017. 
[15] Drina National Park, Study for the designation of a protected area. Republic Institute for Protection of Cultural, Historical and Natural Heritage, Banja Luka, 2015.

[16] Nezirović, S., Tourism Potentials of Srebrenica: Monograph, Municipality of Srebrenica, Srebrenica, 2008.

[17] Nezirović,S.,Natural-geographic and socio-geographical determinants of tourist-geographical development of the region of Northeast Bosnia: doctoral dissertation, Department of Geography, Faculty of Science, University of Sarajevo, Sarajevo, 2012.

[18] Nezirović, S.,Tourism Resources of the Region of Northeast Bosnia, Scientific Monograph, Department of Geography, Faculty of Science, University of Sarajevo, Sarajevo, 2018.

[19] Nezirović, S., Natural characteristics of Spa Spa in northeastern Bosnia, Novi Sad, 2009.

[20] Basic geological map. R: 1:100.000, Ljubovija sheet, L-34-135, RO Geoinzenjering Sarajevo, OOUR Institute for Geology Ilidža and RO Geological Institute Belgrade 1968, Belgrade, 1977.

[21] Basic geological map. R: 1: 100.000, Višegrad sheet, K- 34-3, RO Geoinženjering Sarajevo, OOUR Institute for Geology Ilidža and RO Geological Institute Belgrade 1970-1980, Belgrade, 1986.

[22] Papić, R., Geographical Overview X, DG BiH, economic-geographic characteristics of the central part of eastern Bosnia, Sarajevo, 1966, 63-87.

[23] Official Gazette TK 9/06, Spatial plan for the areas of TK 2005-2015, Tuzla, 2008.

[24] Statistical Yearbook of RS, Banja Luka, 2009.

[25] Federal Hydrometeorological Institute, Meteorological Yearbooks 1971-1991, Belgrade,1991.

[26] Separat SR Bosnia and Herzegovina, Yugoslav Lexicographic Institute, Zagreb, 1983, 29-30.

[27] Official Gazette TK 9/06, Spatial plan for the areas of TK 2005-2015, Tuzla, 2008.

[28] Stojakovic, J., Tourism offer of Tuzla region, PMF, Belgrade,1991.

\footnotetext{
*Corresponding author.

E-mail address: senadanezirovic@ yahoo.com
} 